\title{
The Evolution of Creationist Movements
}

\author{
Nicholas J. Matzke
}

Published online: 15 May 2010

(C) The Author(s) 2010. This article is published with open access at Springerlink.com

\begin{abstract}
Every discipline has its hazards, and for evolution scientists and educators, a major hazard consists of encounters with creationists, their rhetoric, and their attempts to insert antievolutionism into public education. Preparation for this hazard should be a standard part of the background of professional evolutionists. One important piece of this preparation involves understanding the historical origins of creationism within the wider history of western Christianity, especially evangelical Protestantism and its development in the United States. Here, I place the standard histories of "creation science" by Numbers and Larson (covering primarily the early 1900 s to the 1980s) into this larger context (going back to the evangelical split over slavery before the Civil War and during), and then show how the "intelligent design" movement (from the 1980s until the present) fits squarely within the long history of primarily evangelical, biblicist opposition to evolution. The major creationist movements and slogans are identified and also placed into this historical picture. In summary, while creationism has evolved diverse labels and strategies for legal and rhetorical purposes, its fundamental essence remains unchanged. That essence is advocacy of miraculous divine intervention, i.e., special creation, in the history of life, and the claim that science must acknowledge special creation or dire consequences for society will follow.
\end{abstract}

Keywords Creationism - Intelligent design .

Evangelicalism $\cdot$ Fundamentalism $\cdot$ Evolution education

N. J. Matzke $(\bowtie)$

Department of Integrative Biology, University of California, Berkeley, USA

e-mail: matzke@berkeley.edu

\section{Introduction}

It used to be arguable that organized creationism was some bizarre anachronism unique to American culture, but it is now clear that, like McDonald's, creationist movements are spreading around the world along with the influence of American culture (Numbers 2006). Organized creationist movements are primarily a product of American-style Protestant biblical fundamentalism, and as such, they will pop up anywhere this style of fundamentalism becomes popular. This can occur in any place in the world that is accessible to missionaries, churches, and sectarian media; major examples include Brazil, South Korea, and Eastern Europe. In the twenty-first century, the only exceptions are war-torn and Islamic nations (and Islamic nations, of course, have their own form of Islamic fundamentalist opposition to evolution, although the major Turkish group copied much of its material from American creationists [Numbers 2006]).

In the United States itself, on the other hand, creationism may not be getting bigger, but it is definitely big. The longrunning Gallup polls on public attitudes towards evolution and creationism in the United States (Gallup 2010; Newport 2009) have numerous flaws that make naive, face-value interpretation unwise (Branch 2004; Duncan and Geist 2004; DYG Inc. 2000; Padian and Matzke 2009). However, at the very least, these polls indicate that roughly half of the general population harbors significant sympathy for creationism, a conclusion confirmed by comparison of US survey data to that of other industrialized countries (Miller et al. 2006). The numbers decrease when more precise questions are asked, revealing that perhaps $25-30 \%$ of the US population is fundamentalist and resolutely opposed to evolution (DYG Inc. 2000). More importantly, the Gallup results show stasis in US public opinion over the last 30 years. In summary, creationism remains influential in the 
US and is spreading abroad; it is not going away anytime soon.

Given creationism's commonness, many evolution researchers and educators will sooner or later find themselves confronted with creationism in some form, whether a student, a reporter, a family member, or policy battle. They will be asked to respond, prepared or not. Thus it behooves evolutionists to have some understanding of creationism, where it came from, and where it is going.

Where creationism is going is a complex question. Living in an environment with a deep and stable source of popular support, American creationist movements have diversified like a clade that has occupied several different niches and evolved a number of different camouflage adaptations. Creationism in the twenty-first century exists in several different forms and uses an even greater number of names and slogans, some of them deceptive disguises. The forms include several varieties of young-earth creationism and old-earth creationism. The names include "Bible science," "scientific creationism," "creation science," "intelligent design," "baraminology," "basic type biology," and various monikers that are even more calculatedly secularsounding, such as "abrupt appearance" or "sudden appearance." The slogans include "equal time," "teach both sides," "alternatives to evolution," "theory not fact," "teach the controversy," and even language copied from widespread educational lingo, such as "critical thinking" or "critical analysis," "strengths and weaknesses," "teach the full range of views," and "academic freedom."

The persistence of creationism, and the necessity of understanding and effectively opposing creationist movements, can be extremely irritating to those of us who have devoted our careers to researching and teaching about evolution. Why should any time be wasted on those whose religious beliefs cause them to ignore or distort the scientific evidence? However, our situation should be kept in perspective: every science has to deal with the problem of pseudoscience to some degree. Physicists are continually plagued by advocates of perpetual motion machines and relativity-deniers; astronomers have UFOlogists and moonlanding deniers; and chemists have homeopaths. These problems are of smaller scale, to be sure, but we don't have to look far in order to find more significant cases: doctors have to deal with a multitude of quack health remedies, and public health professionals must contend with HIV-AIDS deniers and anti-vaccine activists. In public education, the closest analogy is to other "culture war" topics. Evolution is not the only issue targeted by fundamentalists: others include American and world history, education about sex and abortion, stem cells, and, lately, global warming. In other words, it's not just biology: every field has its particular occupational hazards, and in biology, creationist movements are one of the hazards. Training in any field should include information about the occupational hazards and about how best to react when they arise. For evolution researchers and educators, understanding and responding to creationism and creationist movements should be part of standard professional training and duty. If anything, creationism deserves extra attention compared to the pseudosciences afflicting other disciplines, given its prevalence in the general population and its proven staying power.

In this article, I shall take some steps towards this goal. First, I will lay out three levels at which creationism can be examined: the particular form of creationism, the creationist movement, and the creationist slogan. Second, I will outline the history of creationist movements in the United States, where creationism was (primarily) born and bred. Third, in the light of this history, I will discuss the core meaning of "creationism" and explain why "intelligent design" so clearly falls within it. Finally, I will discuss the slogans of creationist movements and show that they are not really new, but instead have been a constant feature of creationist movements throughout the history of creationism.

By focusing on creationist movements, I am leaving aside several related topics that are also important for evolution educators. Although creationist movements are the primary vehicle that leads to creationist publications, conferences, videos, battles over public policy, and court cases, and therefore to media coverage and headaches for scientists and teachers, such "movements" are made up of a relatively small number of full-time and part-time professional creationists, authors, activists, and fans. The connections between these highly committed creationist leaders, who have detailed views on numerous scientific and theological points, and the millions of people in the general public with generic creationist sympathies but little detailed knowledge of the issues, are often somewhat attenuated. For example, veteran creationism watchers are familiar with the situation in which a creationist student or member of the public has only the vaguest understanding of the creationists movements' arguments, let alone of evolution. Often, their information source will be some half-remembered creationist pamphlet or video, or an article in some denominational magazine, or some claim relayed to them second- or third-hand via a sermon seen at church or heard on a fundamentalist radio or TV station. It is also common to encounter people who are against evolution because they believe in God and have heard the popular but mistaken view that acceptance of evolution means becoming an atheist, but who have virtually no understanding of evolution or earth history. Interacting with these sorts of "unorganized" or "informal" creationists is much different than dealing with politically active creationist movements, and would require another article; readers are referred to several good resources on teaching evolution (Alters and Alters 2001; Scott 2009). 


\section{Forms of Creationism, Creationist Movements, and Creationist Slogans}

It is useful to parse the general phenomenon of "creationism" into at least three different levels: forms of creationism, creationist movements, and creationist slogans. The first and most fundamental level is the form of creationism under discussion. Specifically, what are the detailed theological views of the individual creationist or group in question? How does the creationist interpret the Bible, and as a result of the interpretation, what does the creationist think God created in the past? Which features of the natural world are the result of natural processes, and which are due to divine intervention? The two major forms of creationism are young-earth creationism and old-earth creationism, although there are many variations in the detailed positions taken by individual creationists. Young-earth creationism typically holds that the Earth, the universe, and the major "kinds" of life were all created in six literal days, 6,000-10,000 years ago. Old-earth creationism accepts the standard geological science on the age of the Earth and universe, but denies any significant role for evolution, suggesting that God created various "kinds" of life in thousands or millions of different creation events interspersed over millions of years. Figuring out the form(s) of creationism which are in play in any particular situation is one of the most important keys to understanding what is actually going on when creationists are lobbying for peculiar language in a science standard, or making a peculiar argument about some obscure phenomenon in geology or biology. Figuring out what flavor(s) of creationism you are dealing with is particularly important in secular forums such as academia, public policy disputes, and court cases, in which creationists usually attempt to hide their underlying theology.

Creationist movements consist of an organized group of creationist authors, speakers, activists, and fans who band together in support of a more or less coherent program. The program typically includes a societal goal, a set of strategies to reach it, and an elaborate, though jerryrigged, apologetic argument constructed out of a hodgepodge of claims about science, history, philosophy, law, and theology. The argument is meant to explain why the creationist view is correct despite near-universal disagreement from the thousands of academics with direct expertise in the relevant fields. The societal goal can be explicitly political, such as getting the government to adopt pro-creationist or anti-evolutionary policies. Or the goal can be more general, especially after a political or legal defeat puts the policy goals out of reach. Such goals include fighting atheism (or at least buttressing the faith of believers, especially young believers, confronted with atheism), and fighting doctrinal backsliding within the evangelical population and evangelical institutions such as denominations, churches, and schools. Creationist movements typically are closely associated with creationist organizations that are devoted to promoting the movement. For example, the "intelligent design" movement is headquartered at the Discovery Institute and allied with the Foundation for Thought and Ethics. "Scientific creationism" and "creation science" have the Institute for Creationism Research, Answers in Genesis, and the Creation Research Society.

Creationist slogans are short, appealing phrases that mask creationist proposals which, if stated explicitly, would be politically and socially unpopular or even illegal. However, through creative use of vagueness and tactical ambiguity, such slogans frame these proposals as common sense, intellectually rigorous, religiously neutral, scientific, secular proposal that anyone with a sense of fairness and respect for intellectual inquiry would support. For example, laws banning evolution have been unconstitutional since the US Supreme Court struck them down in Epperson $v$ Arkansas (1968), and had an unpleasantly censorious flavor long before. However, proposals that evolution be taught as "theory, not fact" have remained popular. Proposals that public schools teach that God created humans, as stated in a literal interpretation of Genesis, quite obviously establish a particular religious view and are thus blocked by the US Constitution. But creationists hope that proposals which purport to "teach the controversy" over evolution, or to subject evolution to "critical analysis" will be more successful. As the more explicitly creationist proposals have been blocked by the courts, such deceptive slogans have become increasingly popular among creationists.

\section{A Short History of Creationist Movements}

The history of creationist movements from the early $1900 \mathrm{~s}$ until the 1980s has been covered in depth by various authoritative works (e.g., Larson 2003; Moore 2002; Numbers 2006), so only an overview of essential points from those works will be offered here. Numbers' The Creationists: From Scientific Creationism to Intelligent Design (on the history of creationism) and Larson's Trial and Error (on the history of the legal battles) in particular are widely seen as definitive, and within their domain they are. However, they have some weaknesses as introductory resources because their domain is primarily the history leading from the early 1900s to the "creation science" battles of the 1980s (the first edition of Larson's book was in 1985; the first edition of Numbers' was in 1992). This focus was entirely appropriate when creation science was the primary topic of interest. However, once "intelligent design" and post-ID movements became dominant in public creationism disputes, the tight focus of Larson's and 
Numbers' work sometimes seemed to lend support to certain misconceptions promulgated by the ID movement and others who argued that there was a clear distinction between ID and creationism. These disturbingly widespread misconceptions include the idea that "creationism" refers only to young-earth creationism, that old-earth creationists are moderates rather than fundamentalists, and that social battles inspired by rigid interpretations of Bible texts are something that arose with fundamentalism in the early twentieth century, as well as the quite mistaken idea that ID is something wholly different from creationism.

I will argue that these misconceptions become untenable when the history of creationism from the early 1900s to the 1980s is considered within the larger context of (1) American evangelical Christianity in the 1800s (as covered by historians of evangelicalism Marsden and Noll), (2) the persistence of old-earth creationism throughout the 1900s, and (3) the direct relationship of the recently-discovered 1980s history of "intelligent design" to the 1980s history of creation science. This broad historical context shows that "creationism" has always been broader than young-earth creationism; that old-earth creationists are fundamentalists with Bible-based objections to evolution, very much like the youngearthers; and that the social conflict encouraged by rigid interpretation of Bible texts by conservative evangelicals has a long history predating the rise of fundamentalism. The history also shows that ID fits squarely and solidly within the history of twentieth-century creationism and that ID directly continues trends that were already strongly in evidence in the creation science movement. Furthermore, ID sits comfortably within the history of conservative, biblicist ${ }^{1}$ evangelicalism writ large.

\section{The Roots of American Religion}

The history of creationism over the last 200 years is inextricably tied to the history of religion in the West, particularly America, and to reactions to the continuing developments in science, theology, and education in the wake of the Enlightenment. Here, "religion" means primarily Christianity (although occasionally Jewish or Islamic actors enter the story in the last few decades). "Christianity" means primarily Protestantism (although Catholics occa-

\footnotetext{
${ }^{1}$ The term "biblicist" refers to theologies that emphasize the Bible text much more heavily than other potential sources of authority, such as church tradition, ecclesiastical authority, past theologians, science, etc. The term includes biblical literalism but is somewhat more broad, including the "literal where possible" hermeneutic and the doctrine of biblical inerrancy if taken in a broad sense, such that the original text of the Bible is held to be inerrant not just with respect to matters of faith and morals, but also matters of history and science, even if the text is not always taken literally. Fundamentalism and conservative evangelicalism have a very strong biblicist streak.
}

sionally appear in the story), and "Protestantism" means primarily the evangelical, "Reformed" theological tradition that traces back to Reformation leader John Calvin (although Lutherans and others occasionally appear in the story). The word "evangelical" in this broad sense refers to revivalist-influenced Protestantism that was characterized by vigorous preaching to large crowds, traveling preachers, and large numbers of emotional conversions and "bornagain" experiences. The First Great Awakening (in the mid1700s, before the American Revolution) and the Second Great Awakening (in the early 1800s) were major revivalist movements, responsible for the expansion of the Baptist and Methodist churches into major players in the American religious scene (Marsden 1991).

The Reformed theological tradition is known for its rather severe doctrines such as predestination, which is the view that since God is all-knowing and all-controlling, he knew before the Universe was created who will go to Heaven or Hell-these "elect" are foreordained. Such doctrines are ultimately deduced from interpretation of Bible passages. This highlights a crucial doctrine of the Reformation, "sola scriptura," according to which the Bible is the sole ultimate religious authority, without the additional authorities used by Catholics such as church tradition or Papal authority. Presbyterian and Reformed denominations are the direct descendants of the Calvinist tradition, but Calvinism was widely influential in many others (Anglicans, Baptists, etc.). Lutheranism was another major branch of Reformation Protestantism, but made a less radical break with Catholicism. Lutheranism shared the Calvinists' commitment to sola scriptura, but did not accept strict predestination. A difference between Calvinism and Lutheranism that is important for our discussion concerns their attitudes towards church and state. Calvinists tended to view divine law as absolute and all-encompassing, ideally controlling government and the entire society; Calvin himself effectively established a theocracy in Geneva in the mid-1500s. On the other hand, Lutherans tended to believe that the sacred and secular were two separate kingdoms, and more readily cede secular affairs to the state (not coincidentally, Luther relied heavily on the support and protection of German princes), although the Lutheran church nevertheless became the state-established church in much of Germany and Scandinavia.

Calvinist religion has been hugely influential in American history since before the Revolution. Many of the religious dissidents who came to colonial America, such as the Puritans, were Calvinist and were fleeing oppression from government-established denominations in European states. In America, they set up their own communities along their own strict religious lines; a famous example is the 1630 Massachusetts Bay Colony, led by John Winthrop and his vision that it would be a "city upon a hill," a Puritan 
society setting a example for all the world to see (Noll 1992). By the time of the American Revolution, the colonies were populated by diverse religious groups, with some colonies having no state-established church, others having established Puritan-derived churches, and some having established Anglican churches. In the postRevolution United States, it was obviously impossible that the government would establish the Anglican church, seeing as a war had just been fought to throw off English rule, and Anglican clergy tended to be loyal to England. No other religious denomination had anything close to a majority. Even strong Calvinists with instincts towards instituting divine law in government found themselves preferring the disestablishment of religion, rather than risking government infringement of their own religious freedom through the establishment of the wrong religion (Noll 2002). Finally, many of the Founding Fathers were Deists or Unitarians who were also strongly committed to freedom of religion (Holmes 2006). All of these forces combined to produce the strong language in the First Amendment: "Congress shall make no law respecting an establishment of religion, or prohibiting the free exercise thereof."

\section{Evangelicalism in Nineteenth-Century America}

One might naively think that disestablishing religion would weaken it, but historically the opposite was the case (Noll 2002). The Protestant denominations had actually been constrained by state establishment of religion - either a denomination was suppressed by the government, or, if the denomination became established, it had to enter into the inevitable compromises that must be made in politics and administration. Government funding always comes with strings attached. These sorts of moderating influences disappeared with the disestablishment of religion, and as a result it was almost as if the lid was taken off an already vigorous American religious scene. As the settlers headed west, preachers and King James Bibles went with them. With minimal governmental authority and no official religious authority, the only guide to faith and morals was the Bible, as read, in English, by an inconsistently educated nineteenth-century reader, one with a penchant for "common-sense," "face-value," basically literalist interpretation. Religion became entrepreneurial, with different denominations and preachers competing for the most exciting and attractive messages. Numerous novel interpretations of the Bible and Christianity emerged from this chaotic scene. Modern descendants of early nineteenth-century American theological creativity include the Mormons and the SeventhDay Adventists.

On the East Coast, the situation was less chaotic, but the influence of what Noll 2002 calls America's method of reading and interpreting the Bible-the "Reformed literal hermeneutic"-was no less significant. Presbyterian theologians, most famously associated with Princeton, became some of the most significant voices. This way of reading the Bible was not as crude as the settlers', but still was committed to "common sense" interpretation. In fact, the Reformed literal hermeneutic was closely allied to early modern science (Marsden 2006). "Early modern" scienceroughly, science in the 1600 s and 1700 s - was thought to be based on induction - surveying a wide body of facts and then trying to extract some "laws" or systematic generalizations. Hypotheses and "theory" were avoided as extraneous and speculative, as in the phrase of then-towering scientific authority, Newton (1643-1727): "hypothesis non fingo" ("I feign no hypothesis," Newton's reply to the question of the cause of gravity). This form of inductionheavy, "speculation-free" science is often called "Baconian" science, after Francis Bacon (1561-1626), who was allegedly an early proponent. Reformed theologians of the $1800 \mathrm{~s}$ viewed theology as a science that operated on Baconian terms, with the Bible as the data. It is not much of an exaggeration to say that theologians often assessed controversial questions by discovering and weighing the Bible verses on each side. A leading Princetonian, Charles Hodge (1797-1878), wrote in his 1871 Systematic Theology:

If natural science be concerned with the facts and laws of nature, theology is concerned with the facts and the principles of the Bible. If the object of the one be to arrange and systematize the facts of the external world, and to ascertain the laws by which they are determined; the object of the other is to systematize the facts of the Bible, and ascertain the principles or general truths which those facts involve. (quoted in Marsden 2006)

Evangelical religion, Baconian science (including the Argument from Design, in which the seemingly obvious design of the universe, especially in biology, was taken to provide inductive support for the existence of a Designer), and scientific theology based on the Reformed literal hermeneutic combined into a powerful, appealing Protestant Christian worldview. According to Noll (2002), this evangelical worldview became the dominant American religion by the mid-nineteenth century, and was practically a de facto state religion, unestablished though it was. But this harmonious situation was not destined to last. Trouble arose over slavery. On this issue, the Bible was the nearuniversal authority across the country, much of which had been won over to evangelical Protestantism in preceding decades. Many felt the "spirit" of the Bible was against slavery. Unfortunately, the words in the text clearly 
indicated that Jesus, among others, did not condemn slavery; and indeed various passages throughout the Bible seemed to endorse it. Hodge, a leading conservative Presbyterian theologian but also a Northerner, was stuck arguing that the Bible allowed slavery but that it should be eliminated anyway (Noll 2002). Before the Civil War, the Baptist, Methodist, and Presbyterian churches split into northern and southern denominations (e.g., the modern Southern Baptists) over the slavery question. Noll summarizes,

Many Northern Bible-readers and not a few in the South felt that slavery was evil. They somehow knew the Bible supported them in that feeling. Yet when it came to using the Bible as it had been used with such success to evangelize and civilize the United States, the sacred page was snatched out of their hands. Trust in the Bible and reliance upon a Reformed, literal hermeneutic had created a crisis that only bullets, not arguments, could resolve. (Noll 2002, emphasis original)

The North-forced to fight on unfriendly terrain that it had helped to create- lost the exegetical war. The South certainly lost the shooting war. But constructive orthodox theology was the major loser when American believers allowed bullets instead of hermeneutical self-consciousness to determine what the Bible said about slavery. For the history of theology in America, the great tragedy of the Civil War is that the most persuasive theologians were the Rev. Drs. William Tecumseh Sherman and Ulysses S. Grant. (Noll 1998)

The theological conflict over slavery was an early sign of a split developing within American evangelicalism concerning literalist versus more liberal ways of interpreting the Bible. The Southerners lost the war and had to give up on slavery, but Biblicism and opposition to liberalism remained, to resurface again with the rise of the higher criticism of the Bible and evolution.

\section{The Origins of Christian Fundamentalism}

At the beginning of this section, a word about terminology is necessary: "Fundamentalism" in its original sense refers to conservative Christian Protestants who adopted the doctrine of biblical inerrancy in the early twentieth century as a defense of traditional core Christian doctrines such as virgin birth and resurrection of Jesus. The broader usage of the term, referring to religious extremists, extremists of any sort, any strict or dogmatic traditionalist anywhere in history, or even to violent Islamic terrorists, has only become common in the last few decades. The use of the term "fundamentalist" in its original historical sense does not imply any connection to these other meanings (for example, whatever their flaws, American fundamentalists have no significant tradition of violence) (Marsden 1991). Another important term is "biblical inerrancy." Inerrancy is the doctrine that "[b]eing wholly and verbally Godgiven, Scripture is without error or fault in all its teaching, no less in what it states about God's acts in creation, about the events of world history, and about its own literary origins under God, than in its witness to God's saving grace in individual lives." (International Council on Biblical Inerrancy 2010; HTML version available at http://www.reformed.org/documents/icbi. $\mathrm{html}$ ). The doctrine of biblical inerrancy was formalized by Hodge and his successors at Princeton such as B. B. Warfield and J. Gresham Machen, although its advocates claim it as a long-standing Christian tradition that only required explicit statement once challenges to traditional Christianity arose in the 1800 s.

Although opposition to evolution now seems to be almost one of the defining features of fundamentalism, outright hostility to evolution was a relatively late addition to a movement born for other reasons. Geologists established in the early 1800s that the Earth was ancient and that a global Noah's Flood was unsupportable by sedimentary data. These conclusions were opposed for a time by a few "scriptural geologists," but even this opposition had died out in educated circles, both secular and religious, by the time Darwin published Origin of Species in 1859. (Whether support for a young earth and a global flood had died out among the less-educated religious public and conservative ministers is harder to assess; e.g., Noll [2002] shows a leading minister and theologian in the South supporting biblical literalism on both geology and slavery in 1860, with the Civil War imminent.) The Origin initiated a new round of controversy, this time over common ancestry of animals (particularly humans and apes) and over Darwin's primary mechanism of change, natural selection. Darwin succeeded in convincing the educated world of the reality of common ancestry, and of natural selection, but the question of whether natural selection was a major mechanism of evolutionary change remained controversial until the Modern Synthesis of natural selection and Mendelian genetics in the 1930s-1940s. (In fact, in the late 1800 s and early 1900 s, while descent with modification remained secure, Darwin's selectionist theory was temporarily "eclipsed" by alternative evolutionary ideas such as mutationism, Neo-Lamarckianism, and orthogenesis [Bowler 1983; Gould 2002].)

Conservative theological opposition to evolution was in evidence in the late 1800s. For example, in 1874, Hodge asked, "What is Darwinism?" and concluded "It is atheism" (Hodge 1874). However, although conservative evangelicals often indicated discomfort with evolution, such opposition 
was neither organized nor particularly vociferous. Even in the beginnings of the fundamentalist movement, there was some room for evolution. "Fundamentalism" takes its name from a series of articles defending traditional Christianity against the liberalness of scholarly "higher criticism" of the Bible text, in which scholars concluded that the Bible was a very human product of centuries of editing and redacting. The articles were collectively entitled The Fundamentals, and were originally published between 1910 and 1915 by the Bible Institute of Los Angeles (BIOLA) (The Fundamentals were edited in part by conservative apologist R. A. Torrey [1856-1928], the founder of BIOLA, who also edited the Institute's journal, The King's Business.) All three endeavors were funded by Lyman and Milton Stewart, brothers who made their fortunes in the Southern California oil business. Interestingly, early "fundamentalism" does not appear to have been as anti-evolutionary as the later movement. Noll has noted that the editors and authors of The Fundamentals were comfortable with an ancient Earth, and that even leading Fundamentals writers, such as Scottish Presbyterian James Orr and American Presbyterian B. B. Warfield (who occupied the Charles Hodge Chair at the then-conservative Princeton Theological Seminary), "allowed for large-scale evolution in order to explain God's way of creating plants, animals, and even the human body" (Noll 1994). However, the authors always put some limit on evolution. For example, Orr still invoked divine intervention to account for the origin of life and of human consciousness. He also put significant faith in the idea that the "eclipse" of Darwin's gradualist, selectionist version of evolution was an indication that science would permanently move towards more teleology-friendly theories (Orr 1910-1915a, 19101915b, 1910-1915c).

Evolution only became a dominant issue in the late 1910s and early 1920s. Intradenominational disputes between modernist and fundamentalist views of the Bible were combined with larger cultural splits, such as the bitter dispute over American intervention in World War I (modernists tended to be war boosters and support interventionism, fundamentalists tended to be isolationist) (Marsden 1991, 2006), and the societal turmoil, weakening of traditional mores, and loss of faith in "progress" that followed the war. Fundamentalists like BIOLA's Torrey, and the famous William Jennings Bryan (Woodrow Wilson's Secretary of State, before resigning in protest of Wilson's pro-war policies), began to scapegoat evolutionary theory as the common cause of German militarism, societal decay, and loss of faith in traditional Christian doctrines (Torrey 1918; Bryan 1921). This provided the spark for a culture war, and the dramatic increase in the number of public high schools in the early 1900s (Larson 2003) provided the tinder. Unlike primary schools, high schools were advanced enough to offer specialized subjects like biology. In the 1920s, as now, evolution was a long-standing core theory in the biological sciences, and thus was included in biology textbooks. Fundamentalists thought of this as the last straw; the influences that corrupted Germany and academia were now being thrust into American towns and families via the schooling of children.

The First Creationist Movement: Banning Evolution (1920-1968)

In the early 1920s, Bryan launched a nationwide crusade to ban evolution in high schools and succeeded in several states, including Tennessee. The Tennessee law was challenged by the American Civil Liberties Union, which had recently been formed in order to defend the civil liberties of antiwar protestors against then-harsh governmental suppression. The ACLU was looking for a case to increase its prominence, and sought a Tennessee teacher willing to challenge the law. Teacher John Scopes from Dayton volunteered, leading to the evolution "trial of the century" (the first of several), complete with Bryan as an attorney for the state prosecution, and the most renowned defense attorney in the country, Clarence Darrow, as a lawyer for the defense. Darrow's involvement was somewhat awkward for the defense since he was an outspoken agnostic and was after bigger fish than simply the right to teach evolution-specifically, Darrow wanted to criticize fundamentalism at large. After the judge destroyed the defense case by barring scientific expert witnesses, Darrow somehow goaded Bryan himself into taking the stand. Darrow proceeded to put fundamentalism itself on trial through a cross-examination of Bryan, embarrassing him with uncomfortable questions about Bible stories. The national press declared Darrow the winner and fundamentalism slain, particularly when Bryan died five days after the trial concluded.

It is true that fundamentalism, in the public sphere at least, went into rapid decline after the Scopes Trial. Creationism followed suit: "[O]rganized creationism in North America appeared to be all but dead during the second quarter or so of the twentieth century" (Numbers 2006). By 1955, the fundamentalists seemed so much to belong to the remote, ignorant past that they could safely be used as a metaphor for the anti-communist McCarthyists in the play Inherit the Wind. However, in reality, neither fundamentalists nor their influence on evolution education had gone away. Scopes had been convicted and fined in 1925, and although his conviction was overturned on a technicality in 1927, Tennessee's ban on teaching evolution remained on the books. Several other states and local jurisdictions banned evolution, and widespread hostility persisted among fundamentalist churches and the teachers, parents and students who attended them, 
leading to the suppression of evolution in textbooks and biology curricula for generations. Fundamentalism as a movement did not go away, either. After being rejected by liberals and moderates in the media and in their own denominations, fundamentalists tended to become "separationist," forming their own denominations, colleges, and media outlets. A prominent example was William Jennings Bryan College, founded in 1930 in Dayton to commemorate the memory of Bryan.

A distinction between "fundamentalism" and "evangelicalism" began to emerge in the 1940s and 1950s when a number of leading conservative Protestants, while remaining full supporters of traditional fundamentalist doctrines like inerrancy, rejected the separationism and militancy that had come to characterize fundamentalism. They called themselves "neo-evangelicals"-later just "evangelicals" - and were most strongly associated with institutions like the National Association of Evangelicals, Christianity Today magazine (a newsmagazine for the evangelical population), and evangelist Billy Graham. Sometimes evangelicals are placed (or selfconsciously place themselves) in the "middle" between fundamentalist and liberal or modernist Christians (e.g., Mead 2006), and some fundamentalists were sufficiently doctrinaire to declare "evangelicals" apostates from the true faith. But often it is very difficult to tell the difference; the leading historian of the subject, George Marsden, only half-jokingly resorted to the statement "[a] fundamentalist is an evangelical who is angry about something" (Marsden 1991). There is a great deal more that could be said (Marsden 1991, 2006), but to summarize as fairly as possible: fundamentalism is for all practical purposes identical with the conservative wing of evangelicalism, although someone who self-labels as fundamentalist is likely to be at the extremely conservative end of conservative evangelicals. Modern evangelicalism writ large is broader than fundamentalism, and does have a moderate wing (members of which can be politically centrist, for instance), although there is not much of a liberal wing. Despite evangelicalism's bigger tent, the center of gravity of evangelicalism remains well within the conservative wing. To cash out this terminology as it pertains to creationism: moderate evangelicals are typically accepting of theistic evolution (the religious belief that God used evolutionary processes to shape life on Earth), while conservative evangelicals are deeply suspicious of evolution, favoring either old-earth creationism (like most of the self-described "fundamentalists" of the 1920s, including Torrey and Bryan) or young-earth creationism (like most of the self-described "fundamentalists" of the 1970s and later).

While creationism was common among evangelical and fundamentalist leaders, creationism that specifically argued for a young Earth was relatively rare until the 1960s. The situation is less clear for the laity; the opinions of individuals with no scientific background on somewhat esoteric issues like the Earth's age can be quite vague, and it is possible that many people went most of their lives without thinking much about the history of the Earth beyond Bible stories learned in Sunday school. Most of the leaders, though, accepted some theory of Bible interpretation that allowed an old Earth, such as "Gap Theory," the idea that millions of years of geological history occurred between God's action in first and second verse of Genesis and his subsequent actions in the second verse; proponents included mid-century creationist debater and apologist Harry Rimmer. Another interpretation was "Day-Age Theory," which stated that the "days" of Genesis represented millions of years; proponents included Bryan. Finally, "progressive creationism," the idea that God intervened many times in Earth history to create new groups of organisms, was promoted by BIOLA theologian and American Scientific Affiliation (ASA) ally Bernard Ramm. Such old-earth views were popular in the ASA (founded in 1941), an association of evangelicals with advanced scientific degrees that, like the neo-evangelicals, was committed to biblical authority, but, at least initially, was not particularly interested in picking fights with evolutionists (Numbers 2006). In the mid-twentieth century, young-earth creationism was promoted mostly by Seventhday Adventists, conservative Lutherans, and other extreme literalists; their intellectual leader was an Adventist "flood geology" advocate, George McCready Price. Although a minority, young-earthers eagerly joined the ASA and tried to convert its leadership to the young-earth view. This lead to years of debate with the ASA leadership, which was never converted and regularly rejected articles promoting flood geology (Numbers 2006).

Eventually the exasperated young-earthers formed their own society, the Creation Research Society, founded in 1963 to provide scientific support for young-earth creationism, including flood geology and special creation of biological "kinds." The word "kind" has special significance in creationist literature, deriving from their interpretation of Bible verses such as Genesis 1:25 (King James Version): "And God made the beast of the earth after his kind, and cattle after their kind, and everything that creepeth upon the earth after his kind: and God saw that it was good." Creationists take this to mean that it is the inerrant word of God that it is impossible for a new "kind" of organism to originate through evolution. Even accepting biblical inerrancy, this seems to be a rather elaborate overinterpretation of the text. Nevertheless, young-earth creationists have developed an entire pseudotheory about "created kinds," which they translate to Hebrew as "baramins," and study with "baraminology." For more 
discussion, see Matzke and Gross 2006 and Scott and Matzke 2007. Although slightly less explicit about it (they don't use the baraminology terminology), old-earth creationists and almost all ID advocates believe that evolution can only occur "within the kind."

The CRS was organized around hydraulic engineer Henry Morris and a wildly successful book he coauthored with theologian John Whitcomb, The Genesis Flood (Whitcomb and Morris 1961). This book contained a detailed argument for the proposition that the text of the Bible could be properly interpreted only as supporting a young Earth and the Genesis days as literal 24-hour days, combined with a detailed scientific argument that scientific evidence was reconcilable with this view. This combination was immensely appealing to evangelicals at large (if not to evangelical intellectuals at places like the ASA). Like evangelicals today, they maintained a strong commitment to biblical authority and a strong emotional desire for an easily understandable face-value interpretation of the biblical text ("God says it, I believe it, that settles it!" being a popular phrase). They also had a strong respect for the "common sense" and demonstrative character of science, and its resulting cognitive and cultural authority. As noted above, it is not far off to say that fundamentalist theologians, and their antecedents such as the Princeton theologians, viewed theology as a science, with the Bible text as the data, and with controversial questions to be decided by weighing the Bible verses on each side. Since the prominent twentiethcentury conflict between science and the literal reading of Genesis had caused cognitive dissonance for many evangelicals, Genesis Flood provided relief by apparently reconciling the two. Genesis Flood is considered the most important creationist book of the twentieth century, and Henry Morris the most important creationist, for they transformed young-earth creationism from a somewhat obscure doctrine of extreme fundamentalists and spread it far and wide across evangelical churches.

\section{The Second Creationist Movement: "Creation Science" (1968-1987)}

The 1960s revolution in creationist opinion was primarily an affair internal to the community of evangelicals. However, as in the 1920s, developments on the public school front were soon to produce a clash. The Russian launch of Sputnik in 1957 provoked widespread concern that the United States was falling behind the communists in science. As a result, the federal government poured money into science education via the National Science Foundation. One result was the Biological Sciences Curriculum Study (BSCS), founded in 1958, which produced a series of new up-to-date biology textbooks featuring up-to-date science, including, of course, evolution. These books were widely promoted in public schools; however, evolution was still banned in many states and local districts by Scopes-era laws. Teachers using BSCS textbooks in these states were thus in a legal quandary, soon leading to another attempt to overturn the bans in the courts. This situation produced the 1968 Epperson v Arkansas decision, wherein the Supreme Court ruled 9-0 that banning evolution was unconstitutional: it violated the First Amendment's prohibition of government establishment of religion because "[i]t is clear that fundamentalist sectarian conviction was and is the law's reason for existence" (1968).

These developments did not go unnoticed in the evangelical world. A survey of the "moderate" neoevangelical Christianity Today's offerings on the evolution issue in 1968 provides some estimate of where the center of evangelical opinion lay at the time. In March 1968 the editors of Christianity Today noted the upcoming Supreme Court case and stated that "[i]t is likely that the US Supreme Court will strike down the 1928 Arkansas 'antievolutionary law," but they also argued that creationism should retain a place in the schools:

A court decision that upholds academic freedom on this matter should not, however, obscure the fact that our teachers are also obliged to uphold academic responsibility. In far too many schools, the study of man's origin is discussed only in terms of naturalistic evolvement, which for all practical purposes is treated as fact. Virtually no consideration is given to biblical documents that record man's creation as a special act of God. Such an omission is a violation of academic responsibility, and parents who share this view ought to register it in Parent-Teacher Associations. If, as Miss [sic] Epperson claims, it is a teacher's duty to teach the various aspects of being, then our schools must honestly consider biblical creationism as well as evolutionary theory, which is far from being proved. Teachers have a responsibility to consider the full range of views on this topic and to take care not to confuse subjective interpretation with scientific data. (Anonymous 1968b, emphasis original)

In September, the magazine published young-earther A. E. Wilder-Smith's extremely favorable - wholly uncriticalreview of an anthology of "scientific creationist" (WilderSmith 1968) essays by Henry Morris and others. In December, less than a month after the Supreme Court's Epperson decision, the editors offered their take on the unbanning of teaching evolution:

...Mrs. Epperson's victory is a somewhat hollow one. Her efforts have removed from the books a law that really should not have been there and was never enforced. On the other hand, in recent years it hasn't 
been the theory of evolution that has been shortchanged in biology classrooms. While we would maintain that the state should not be allowed to force the teaching of the doctrine of creation in public schools, Christians should insist on "equal time" for a fair presentation of the biblical position as a valid explanation for the origin of man. (Anonymous 1968a)

The last sentence may seem somewhat self-contradictory, but probably reflects the newly-emerging sentiment among scientific creationists that biblical creationism could be presented in public schools as an alternative scientific view. In a key passage of his history of creationism, Numbers suggests that the "scientific creationism" language arose when creationists, starting in 1966, attempted to get equal time for creationism in California schools:

The transmogrification of creationism from religion to science took place in direct response to the events in California, which encouraged creationists to believe that they could squeeze into science classrooms simply by shedding superfluous biblical weight. "Creationism is on the way back," announced Morris, "this time not primarily as a religious belief, but as an alternative scientific explanation of the world in which we live." (Numbers 2006)

The scientific creationism movement grew throughout the 1970s, producing the Creation Research Society's textbook, Biology: A Search for Order in Complexity (Moore and Slusher 1970), and two different versions of Henry Morris' textbook Scientific Creationism (Morris 1974). The regular edition had Bible quotes mixed in with the science, and the "Public School Edition" was identical except for having been cleansed of these quotes. The Creation Science Research Center (CSRC), established in 1970, was devoted to creationist political activism primarily in California. After a split between the political CSRC and the more "research"-focused Morris, the Institute for Creation Research (ICR) was established in 1972 (Numbers 2006). The movement also experienced some court defeats; the CRS textbook was ruled unconstitutional in Hendren $v$. Campbell (1977), and a new Tennessee law mandating equal treatment for biblical creationism failed in Daniel $v$. Waters (1975). Yet creationists were undeterred. Wendell Bird, a creationist law student, authored a law review article (Bird 1978) arguing that these creationist policies had lost because they constituted religious creationism; however, scientific creationism "could be constructed from scientific discussion of empirical evidence divorced from theological reasoning and terminology" and would thus be constitutionally taught in a public school (Larson 2003, quoting Bird p. 147). Bird joined the ICR as a legal advisor and updated the ICR's model "equal time" resolution, which was aimed at pro-creationist school boards. The resolution was distributed across the country in 1979, including a disclaimer stating that it was aimed at school boards rather than legislatures. Nevertheless, creationist activists, led by Paul Ellwanger, a Catholic young-earther, converted it into a legislative proposal and distributed it to legislators. In 1980 and 1981, legislation mandating equal time for creation science was proposed in dozens of state legislatures (Larson 2003). Such bills passed in two states, Arkansas and Louisiana, provoking the expected ACLUsponsored challenges that would put creation science and Bird's arguments for its legality to the test.

The Arkansas bill went to trial in short order. Unlike the Scopes Trial, expert witnesses were allowed. Testifying for the plaintiffs, famous evolutionary biologists (such as Stephen Jay Gould and Francisco Ayala) as well as other experts (such as historian and evangelical George Marsden, cited above) faced off against less-than-famous creation scientists. The decision was a thorough, crushing, and embarrassing defeat for the previously cocksure creationists (McLean v. Arkansas Board of Education 1982). The shocked reactions from all corners of the fundamentalist and evangelical community indicated widespread naiveté about the quality of creationists' scientific and legal arguments. An example is the May 1982 cover story of Moody Monthly, the magazine of the venerable conservative evangelical Moody Bible Institute (founded 1886), which declared that Arkansas was "[w]here creationism lost its shirt" (Mawyer 1982); other examples are reviewed in Matzke (2009).

But the creationists saw a second chance coming with the Louisiana bill. They felt their odds were better, since "creation science" was even more vaguely defined in that bill than in the Arkansas bill- this time avoiding references to a young earth and global flood. Furthermore, Bird himself had been deputized by the state to defend the statute (whereas the Arkansas law was defended by the state attorney general, a committed litigator but less than an expert on the topic). Bird assembled a list of expert witnesses and a massive brief in support of the contention that creation science really was scientific.

However, since a trial had already been held over the Arkansas law, the ACLU argued successfully that the Louisiana case could be decided by summary judgment. Due to legal maneuvering, this did not happen until 1984. Summary judgment went against the creationists; the official record of the bill's passage contained fundamentalist remarks by the Louisiana legislators, making it extremely difficult to convince the court that the creation science bill was a wholly secular endeavor. Doubling down, creationists made a series of appeals all the way to the Supreme Court, losing each one, until Edwards v. Aguillard 
(1987) made it the law of the land that "creation science" was unconstitutional.

\section{The Third Creationist Movement: "Intelligent Design"} (1989-2005)

It has been shown in detail elsewhere (e.g., Matzke 2009; Scott and Matzke 2007) that "intelligent design" is a direct descendant of the watered-down-for-courts "creation science" that Bird was defending in the Edwards case. In short, ID's early "designers" were a cooperating group of young-earth and old-earth creationists who were attempting to come up with a textbook that would provide students with the sanitized form of creation science that they hoped would be legal in public schools if equal-time laws were ruled constitutional. All of the main players in the writing and production of this textbook were also closely involved in defending the Arkansas and/or Louisiana bills (or at least had been prepared as expert witnesses in the event that the Louisiana case went to trial), or had been explicit defenders of either creation science or "equal time" approaches (Matzke 2009). The textbook they were working on went through many drafts and titles from 1983-1989, and evolved throughout that time period. The result was that a 1983 draft entitled Creation Biology Textbook Supplement -which was explicitly devoted to "creation science"ended up as a textbook devoted to "intelligent design" after the Supreme Court defeat of creation science. Unsurprisingly, the book's authors and promoters claimed that it was pure science and thus the farthest thing imaginable from creation science. This textbook, the now-famous Of Pandas and People (or Pandas), was first published in 1989. It was the first book to use terms like "intelligent design" and "design proponents" systematically, the first to put "intelligent design" in a glossary, and the first to claim it as something wholly distinct from religion and creationism.

The post-Pandas history of the ID movement extends from the 1990s until the Kitzmiller case (2005), which was the result of a Dover, Pennsylvania, school board's adoption of a policy that promoted ID with Pandas as the recommended reference book (initially, 50-plus copies of Pandas were to be placed in biology classrooms; when the lawsuit was filed, they were hastily moved to the school library). This policy, which required science teachers to read a pro-ID statement to their students, was subsequently ruled unconstitutional in dramatic fashion. The 1990s history of ID is much more generally known and will not be reviewed here; readers are referred to standard works (Forrest and Gross 2007; Pennock 1999). It is important to note that until the Kitzmiller case, much of the attention that ID received from academics, and even historians, was focused on personalities like Phillip Johnson and Michael Behe. These people were indeed the leading spokesmen for
ID in the 1990s, and were a great help in spreading ID far and wide. Similarly, the Discovery Institute (DI) has been the dominant promoter of ID since it got into the creationism business in 1996 with the establishment of the Center for the Renewal of Science and Culture (now the Center for Science and Culture). But these people had little to do with the actual origin of "intelligent design"- rather, they, like the apostle Paul, were converts to a cause started by others.

In passing, it is worth noting that in the wake of the revelations of Pandas' creationist history (discussed in more detail below), some have tried to dismiss Pandas as some kind of isolated instance of ID being confused with creationism, as if it was a crude mistake by ignorant creationists, disconnected from the rest of the (allegedly non-creationist) ID movement. Notably, the Discovery Institute has not tried this argument-most of the major DI fellows are authors, reviewers, or endorsers of the book. However, other ID fans are sometimes less hesitant; in a particularly vociferous online discussion, a number of them claimed that Pandas was an "obscure, irrelevant book," that it was "unimportant in every meaningful way," that it was "a horrible book for learning about ID," and that "[t]he only thing Pandas would demonstrate to reasonable people is that the authors of Pandas may have been creationists" (Anonymous 2006).

Nothing could be more hopeless than the attempt to distance ID from Pandas. Apart from being the origin of ID as a term, Pandas has been intimately connected to the ID movement throughout its history until the Kitzmiller decision. The fact is that Pandas was either authored or endorsed by all of the key personalities in the ID movement. The authors include Charles Thaxton (oldearther, DI fellow), Dean Kenyon (young-earther, DI fellow), Nancy Pearcey (young-earther, former editor of the young-earth Bible-Science Newsletter, DI fellow), Stephen Meyer (old-earther, current head of the Discovery Institute's ID program), and Michael Behe. Although Behe is unlisted as an author, he wrote the new blood-clotting section of the 1993 edition of Pandas - thus making Pandas Behe's first published contribution to ID! Endorsers include DI fellows Michael Behe, Jonathan Wells, and William Dembski (these latter two coauthored a revised edition of Pandas, The Design of Life; Dembski and Wells 2008) and Phillip Johnson, the "godfather" of the ID movement (Pennock 2010). Apart from defending Pandas in court, Behe in an endorsement said "the scholarship in Pandas is top-notch...Pandas is appropriate for use in high schools." Long excerpts from Pandas have been posted on the DI's website and other ID websites since the advent of the internet (Matzke 2009). DI fellows wrote law review articles encouraging the use and constitutionality of Pandas in public schools; these, combined with the infamous 
Wedge document, among other things, make it clear that getting ID and Pandas into the public schools really was a goal of the ID movement, contrary to the movement's Kitzmiller-era denials (Padian and Matzke 2006), and the statements of certain commentators with some combination of gullibility and short memories (e.g., Monton 2009; Ratzsch 2010).

Now, in the wake of the ID movement's Kitzmiller defeat, a fourth creationist movement is emerging; I will discuss its probable shape and future in the conclusion.

\section{What is Creationism?}

As Gould has pointed out, we can attempt to describe ideas through their history, or by identifying some core or essence (Gould 2002). In the case of creationism, the approaches are complementary. We have already examined the history of creationism and surveyed its diversity; having done so, we can make some judgments about its essence. The core idea unifying all the various forms of creationism is the conviction that divine intervention, i.e., special creation, is necessary to explain the diversity of life. It is true that the word "creationism" is occasionally used in broader or narrower senses, but these are special cases that manifestly do not correspond to the main body of historical or present usage. For example, theists who completely accept natural evolution as the best available science will sometimes describe themselves as "creationists"- theists who are evangelical Christians have even adopted the term "evolutionary creationist" as a semi-official term, which they prefer to "theistic evolutionist." Yet they always go on to explain that they are only "creationists" in the very general sense that they believe God created and sustains the universe. Typically, these same individuals are active opponents of creationism in its standard sense, that is, they oppose the insertion of divine intervention into biology, and they explicitly refer to their opponents as "creationists." Recently, some in the "New Atheists" movement have also taken to describing theistic evolutionists as "creationists," basically a move that they use to attempt to discredit theism in general via association with fundamentalists. Unfortunately, they often leave out the important qualifier that theistic evolutionists are some of the staunchest foes of creationism as defined by divine intervention and special creation.

An example of the narrower usage of the term comes from those who argue that the word "creationism" refers only to young-earth creationism or "creation science." This view is popular with intelligent design advocates, who above all else want to avoid the "creationist" label for political and constitutional reasons. It is also sometimes popular with those who have accepted the ID advocates' creationism denials with a bit too much innocence and have not taken the time to get past the chaff thrown up by ID advocates. There are several problems with the narrower definition of creationism. While it is plausible to argue that young-earth creationism was the dominant form in US popular discourse in the 1970s and 1980s, it is impossible to argue that the term "creationism" can be restricted to the young-earth view as a general matter. In the first place, Darwin, who appears to have coined the term in its modern sense (OED 2010), was not arguing against young-earth creationists - his opponents were those such as nineteenthcentury Harvard biologist Louis Agassiz, who accepted the geological timescale of the day, but argued for the special creation of biological groups. Second, as we have seen, the most famous creationist of all time, William Jennings Bryan of Scopes Trial fame, was an old-earth creationist, as were most fundamentalist Christians until the 1960s.

Third, many self-identified "old-earth creationists" have existed and propounded their views throughout the twentieth century. Many old-earth creationists exist today, accepting geology, but arguing vociferously for special creation and vehemently denying any significant role for natural evolution. Proponents of this view include Hugh Ross and his oldearther "Reasons to Believe" ministry. Any definition of "creationism" that excludes old-earth creationism does not reflect reality. Finally, regarding "intelligent design," the movement is essentially an attempt to bring young-earthers and old-earthers together to battle the common enemy of evolution; how can a coalition of young-earth creationists and old-earth creationists (Pennock 1999), fighting the same old battle against evolution, suddenly become something non-creationist? In any case, whenever one takes the time to burrow to the heart of what ID advocates are actually saying, their proposal always boils down to divine intervention in biology, however obliquely stated (Forrest and Gross 2007, see chapters 5 and 9). This is true whether they are talking about the origin of Cambrian phyla, or of humans, or merely the origin of a biochemical complex like the bacterial flagellum, or the origin of new genetic information in the form of a new gene. At every level, divine intervention is implicitly or explicitly invoked. As Darwin put it, creationists think that "at innumerable periods in the earth's history certain elemental atoms have been commanded suddenly to flash into living tissues" (Darwin 1859). The definition of creationism that focuses on divine intervention is the fairest and most accurate representation of not only the historical meaning of the term, but also predominant present meaning. Most importantly, the focus on divine intervention best captures what people have been and are still fighting over.

"Intelligent Design" is Creationism, This Time with Feeling

It is virtually universally agreed among evolutionary scientists and educators that "intelligent design" is just 
another form of creationism with a slicker label- "creationism in a cheap tuxedo" being a popular descriptor (Krishtalka 2001). However, it is nonetheless important to defend this point, since ID advocates themselves continue to vociferously deny that ID is creationism, and certain prominent commentators appear to have been misled by these denials - even after the dramatic revelations about the origins of ID in the Kitzmiller case. An anecdote about how my own views on this question evolved may help to illustrate how a noncreationist might have once come to the position that ID is different from creationism, as well as to illustrate the considerations that ultimately show that this conclusion is flawed, and that ID really is just creationism relabeled.

Back in the late 1990s, when I first heard of "intelligent design," I thought it was cliché and a little flippant to say that "creationism was evolving." Like most eager young science nerds, I was skeptical of ID. But I thought that at least the ID arguments were a step up from the old "creation science" junk that I had heard about when I was growing up. At least the ID people weren't saying that humans lived with dinosaurs because of non-humanlooking footprints near dinosaur trackways in Texas (near which young-earth creationist Carl Baugh has constructed his "Creation Evidence Museum" in Paluxy, Texas). At least the ID guys didn't claim to have found Noah's Ark based on a rock outcropping in an aerial photograph. And, thank goodness, they weren't talking nonsense about the Second Law of Thermodynamics. So maybe, said I, the ID guys deserve a pat on the back for dispensing with the silliest parts of creationism, and for trying to make a serious argument. Perhaps we should give them the benefit of the doubt, and attempt to answer their scientific-sounding arguments with science, instead of unfairly dismissing them by association with "creationists."

As it turned out, my innocent early beliefs were mostly wrong. Cliché or not, stating that ID is creationism relabeled is far more accurate than saying the opposite; in fact, it was literally true that ID was creationism relabeled. As I ended up helping to discover in the Kitzmiller case (Matzke 2006), very much to my own surprise, the "intelligent design" label and related terminology were adopted by creationists after the previous legal strategy, "creation science," was ruled unconstitutional by the Supreme Court in 1987. Terminology like "creation" and "creationist" was deleted from the textbook which became Of Pandas and People, and the terms "intelligent design" and "design proponent" were inserted in their place. In one famous instance (discovered by Barbara Forrest) this find-and-replace process left behind a textual fossil, "cdesign proponentsists," in a draft of the book (Scott and Matzke 2007).

In 2005, in the heated atmosphere of a federal trial, the revelations about Pandas seemed like dramatic and surprising finds, but in retrospect, they should not have been. As I noted in Matzke (2009), close watchers of ID have consistently noted its creationist nature ever since the phrase "intelligent design" was introduced to the debate in the 1989 first edition of Pandas (e.g., Padian 1989; Ruse 1989; Scott 1989). Recently, I have come across evidence that creationism watchers knew what was coming even well before Pandas was published (Bennetta 1988a, 1988b). William J. Bennetta, president of The Textbook League and a longtime activist opposing pseudoscience in textbooks, followed the Edwards case (1981-1987) closely and reviewed the decision and its effects in 1988. Bennetta hazarded some guesses about what creationists would do after the Edwards defeat:

Here are some of the things creationists will be doing most assiduously during the coming decade: .... The creationists will produce a new version of the pseudoscience, and they will try to induce respectable secular publishers to issue books incorporating the new material. They will hope to use the books for validating their litany about teaching "all the evidence" and for validating the misinformation that they will be spreading among science teachers.

Because the term "creation-science" has been sullied most recently in Edwards v. Aguillard, the creationists' new pseudoscience will carry a new name, or perhaps several new names. Its content will be fully sterilized: it will avoid explicit supernaturalism, and it will speak not of any god but of a nebulous "intelligence" or "intelligent cause." It will be much more sophisticated than orthodox "creation-science" because it will shun created "kinds," a worldwide flood, and other topics that clearly point to episodes in the Bible. Its literature will avoid blatant references to the literature of orthodox "creation-science" and will be untainted by any obvious connections to fundamentalist ministries or to fundamentalist publishers. (Bennetta 1988b)

As we now know, the actual term chosen to replace creation science was "intelligent design," but the rest of Bennetta's predictions were eerily accurate (although ID has never really abandoned the commitment to special creation of "created kinds," only that explicit language [Matzke and Gross 2006; Matzke 2009]).

\section{The Sophistication Argument}

The notion that ID is more "sophisticated" than creationism or creation science is somewhat popular even among critics of ID, perhaps because it reinforces the point that ID is a real threat to high-quality science education. It also provides a 
reason for the critics to spend time rebutting ID claims, instead of doing their day jobs. The argument certainly once appealed to me- - I used to envision the creation scientists as incompetent clowns with obvious fundamentalist motivations, and ID seemed to be a refreshing improvement.

However, the greater sophistication of ID with respect to creation science is in reality highly debatable. When one actually goes back and reads creation science literature from the 1970s and 1980s, one finds that it, too, exhibited a similar "sophistication"- the same sort of limited, superficial, and quite peculiar "sophistication" found in ID. Creation scientists used big words, also-it's not as if ID invented this feature of pseudoscience! Similarly, just as ID proponents do now, creation scientists talked about biochemical complexity, misinterpreted cladistics to dismiss fossil evidence of transitional forms, made bizarre probability arguments based on the mistaken assumption that evolution is equivalent to all-at-once chance assembly, and swept any evolution evidence that they couldn't deny under the rug as "microevolution," just like modern ID advocates. As ID proponents do today, creation scientists mined the mainstream scientific literature for quotes that seemed like "gotchas" to naive readers who were unfamiliar with the relevant context and scientific fields. They thereby converted scientists who spent their careers studying evolution and advancing evolutionary theory, like Stephen Jay Gould, into harbingers of evolution's eminent demise.

Creation scientists had, and still have, their own tiny collection of Ph.D.s (in fields of dramatically varying relevance), just as ID does, and these creationists were (and are) occasionally able to slip their work into mainstream journals by eliding their creationist conclusions. Creation scientists likewise had their own in-house "research" journals - on this score, actually, the creation scientists have always been ahead of the ID movement, and remain ahead today. While the ID movement has never managed to keep a journal in permanent production, the creation scientists in comparison have a relatively vigorous collection of journals, including the Creation Research Society Quarterly (published continuously since 1964), Origins Research Journal (published by the Adventist Geoscience Research Institute), and the Answers Research Journal (published by Answers in Genesis).

As can be seen in the history, creation scientists swore up and down (in certain venues, namely legislatures and courts) that they were engaged in a purely secular, nonreligious, scientific activity, wholly appropriate for the public schools, just as ID advocates now swear. And just like ID advocates, creation scientists in other venues, such as churches and fundraising letters, admitted that they were actually on a mission of conservative theist apologetics, and seeking to return the "proper" understanding of God to its "proper" place in academia and education. In all these ways, creation science was just as "sophisticated" as ID. It would take another paper to establish the point rigorously, but the viewpoint that creation science is crude stuff, easily dismissed as junk rather than a serious threat, is very likely a product of the pitched battles of the $1980 \mathrm{~s}$, and the defeats that creation science eventually experienced. In the 1970s, creation science had some popular appeal, just as ID did in the 1990s.

Finally, on the silliness point, ID has a collection of arguments that are just as silly as the creation scientists' arguments about dinosaur footprints and the Second Law of Thermodynamics. ID advocates have actually argued that the color change in peppered moths was not due to bird predation, because peppered moths (allegedly) were once thought to rest on tree trunks, but (allegedly) are now known to rest under tree branches (Wells 2000). Apparently, ID advocates think insectivorous birds can get to tree trunks, but not tree branches (and actually, the data indicate that peppered moths are fairly nonspecific, and rest in both locations, although they tend to prefer shadowed and otherwise somewhat hidden resting places, which makes sense, after all, if they are trying to hide from birds; Majerus 2008).

An especially good example of silliness is the ID assertion that natural processes cannot create new genetic information. ID advocates have recently been pushing this line heavily as of late (Meyer 2009), even in the science standards of some states (see Matzke and Gross 2006, for discussion and refutation of the information argument), and in the ID movement's new textbook, Explore Evolution (Meyer et al. 2007). Interestingly, this talking point, at least in the form of a seemingly technical chemical/mathematical conclusion (there are older, more informal versions throughout the creationist literature), was invented in the 1984 proto-ID book The Mystery of Life's Origins (Thaxton et al. 1984), as a modified version of the creation scientists' Second Law argument (Matzke 2009). It has since grown into one of the top two or three arguments made by ID advocates.

\section{The Argument that ID is Not Religious}

Apart from the evidence that ID is creationism (reviewed or cited above), and the more generic evidence that ID proponents are engaging in religious apologetics in the guise of science (e.g. Forrest and Gross 2007), there is yet another line of argument showing that ID is a form of fundamentalist religion. This returns to our review of the history of evangelicalism and fundamentalism. Historians have argued that fundamentalist opposition to evolution was, in part, an attempt, however quixotic, to return science to its Baconian, theory-free state, and to return the culture to a time when the Bible commanded the same kind of 
cultural authority that science has, particularly with the elites in government and academia. This is expressed in the common creationist statement (actually, misstatement) that they agree with scientists on all the facts, but that the creationists' interpretation of the facts differ. Their hope is that modern culture can be returned to a state similar to that in the early $1800 \mathrm{~s}$, when science was Baconian and didn't conflict with Baconian Bible interpretation, and when this unified biblical, evangelical worldview was the cultural consensus and had great cultural power (Marsden 1991, 2006; Noll 1994).

The same hopes-defeating materialistic evolution and thus returning to this alleged golden age - are expressed in the Wedge document (Discovery 1998; Downey 2006) and numerous other ID publications. For example, the Wedge document replicates the decades-old creationist "tree of evil" imagery (Toumey 1994) wherein evolution is imagined to be the wellspring of every imaginable social evil: "The social consequences of materialism have been devastating...we are convinced that in order to defeat materialism, we must cut it off at its source. That source is scientific materialism...If we view the predominant materialistic science as a giant tree, our [intelligent design] strategy is intended to function as a 'wedge' that...can split the trunk" (Discovery 1998).

Moving further back in history, there are numerous other close material connections between the history of fundamentalism and modern ID. The creation scientists tended to focus on "evolution" versus "creationism," but, like William Jennings Bryan and the other old-earth creationists fighting "Darwinism" in the 1920s (Bryan 1921), the ID movement quite deliberately changed the label of its enemy to "Darwinism," specifically by replacing every instance of the word "evolution" or "evolutionist" with "Darwinism" or "Darwinist" in the 1993 second edition of Pandas (Davis et al. 1993). A more specific example is the Bible Institute of Los Angeles, the school most associated with the rise of fundamentalism, which was eventually renamed Biola College (in 1949), then Biola University (1981), and is now the university most closely associated with the intelligent design movement. Biola hosts annual ID conferences, and employs several DI fellows as faculty, providing the only degree program in the US in which students can take coursework in intelligent design. Biola has also actively support the promotion of Explore Evolution. Yet another historical connection harks back to the Reformed, literalist theologians at Princeton Theological Seminary who provided much of the intellectual foundation for the fundamentalist movement and its theology. DI fellow Jonathan Wells earned his Ph.D. in Religious Studies at Yale University by studying Charles Hodge's critique of Darwinism and defense of the design argument (Wells 1986, 1988). While Dembski was a divinity student at the
Princeton Theological Seminary, he actually co-founded a student group called the Charles Hodge Society, a group which proceeded to recreate the Princeton Theological Review, the journal of the old conservative Presbyterian theologians which became defunct in 1925 (Dembski and Richards 2001).

Finally, it doesn't take much looking before virtually any ID advocate will let down their guard and admit that the real point of studying ID is to return God and purpose to the culture. A recent example is the most recent major ID book, Signature in the Cell by Stephen Meyer, director of the DI Center for Science and Culture. After 450 pages devoted to arguing against the possibility that natural processes can explain the origin of life, Meyer concludes with a section on "Why it Matters" (Meyer 2009). He says,

As a teenager in the mid-1970s, I sensed this absence of meaning in modern life...What heroism, thought or feeling, labor, inspiration, genius, or achievement will last, if impersonal particles are all that ultimately endure? ...Though the theory of intelligent design does not identify the agent responsible for the information - the signature - in the cell, it does affirm that the ultimate cause of life is personal...The case for intelligent design challenges the premise of the materialist credo and holds out the possibility of reversing the philosophy of despair that flows from it. Life is the product of mind; it was intended, purposed, "previsioned." Hence, there may be a reality behind matter that is worth investigating.

If the conscious realities that comprise our personhood have no lasting existence, if life and mind are nothing more than unintended ephemera of the material cosmos, then, as the existential philosophers have recognized, our lives can have no lasting meaning or ultimate purpose. Without a purposedriven universe, there can be no "purpose-driven life." (Meyer 2009)

Meyer's reference to a "purpose-driven life" is of course a direct reference (though without citation) to the massively popular book of the same name (Warren 2002) authored by Rick Warren, a megachurch pastor and one of the leading evangelical voices in America today. In any standard scientific book on the origin of life, this would be quite the odd reference, but with creationist works, even ID works, it is par for the course. The whole point of the exercise of arguing against evolution is to argue for the interventionist, miracle-working God found in the creationists' reading of the Bible. In other words, for ID creationists as well as other creationists, the meaning of life, the universe, and everything is on the line, along 
with the fate of society, over what seems at first glance to be a mere pedestrian question about the scientific correctness of evolution. Henry Morris felt the same way: "Evolution is the root of atheism, of communism, nazism, behaviorism, racism, economic imperialism, militarism, libertinism, anarchism, and all manner of anti-Christian systems of belief and practice" (quoted by Kitcher 2009).

\section{Conclusion: A Fourth Creationist Movement, and What We Should Do About It}

In the wake of the Kitzmiller defeat, it is clear that the ID movement "has played itself out conceptually and is spinning its wheels" (Pennock 2010). However, as in every previous defeat of creationism, the strategies and labels have changed, but the creationists and their core beliefs haven't. The advocates of special creation now mostly eschew pushing "creationism," "creation science," and even "intelligent design" into schools (and ID advocates now claim that they never meant to do so, an obvious falsehood Padian and Matzke 2006). But the very same ID advocates in 2007 produced a new Pandas-like textbook, Explore Evolution (Meyer et al. 2007), which almost completely avoids reference to creationism or ID but nevertheless rehashes many of the traditional, half-baked creationist/ID objections to common ancestry. The book even includes an extensive discussion of Behe's "irreducible complexity" argument about the flagellum (refuted in general and in detail by Pallen and Matzke 2006) and, even more brazenly, argues that the pattern of life's relationships resembles not Darwin's tree of life, but an orchard of life. This is a classic youngearth creationist description of their view of the special creation of separate, unrelated biblical "kinds" (Matzke and Gross 2006). It was probably introduced into the book by Explore Evolution coauthor Paul Nelson, who is both a young-earther and a longtime core member of the ID movement and Discovery Institute.

Instead of "creationists", Explore Evolution speaks of various "critics" of the mainstream evolutionary view. Who are these "critics"? Often they are mainstream scientists who are misrepresented by out-of-context quotes and misleading citations but who are in no reasonable sense critics of common ancestry. Sometimes they are ID proponents or other even stranger pseudoscientists, such as Christian Schwabe, a chemist who apparently thinks that every single living and fossil species has originated independently (but naturally) from chemicals (Schwabe 2001). Only wonks who follow the evolution/creationism issue closely would have any hope of sorting it out; teachers and students - the intended audience-will have no idea they are being swindled.
Explore Evolution is being pushed via the sorts of slogans mentioned in the introduction. After the Kitzmiller defeat, the Discovery Institute intensified its rhetoric about "academic freedom," and began sponsoring "academic freedom" events and policies. In actuality, the ID movement spent years trying to get ID and Pandas into schools by means of state statutes or local school board policies, doing an end run around the academic freedom of teachers and scientists who had used their academic freedom to judge ID unworthy of inclusion in textbooks and curricula (see examples in Scott 2009). The facts of history are again very revealing. "Academic freedom" was a creationist slogan long before 2006. After the 1987 Edwards defeat, the Creation Science Legal Defense Fund actually changed its name to the Academic Freedom Legal Defense Fund (Moore 2002), shortly before the Fund became defunct. Before that, "academic freedom" was prominent part of Wendell Bird's pro-creation science arguments.

Other slogans have similar histories. "Theory not fact" language, at issue in both the Kitzmiller case and the Selman v. Cobb County case (in which evolution disclaimer stickers in textbooks were ruled unconstitutional), traces right back to anti-evolution policies in the 1920s (Scott 2006). It is also a simple and direct expression of fundamentalists' harkening for the good old days of the early 1800 s societal consensus, according to which science and theology were nothing more than simple Baconian induction (arguably, it goes even further back to the Catholic Church's prohibition against Galileo advocating heliocentrism as true). The Discovery Institute's favorite line about teaching "the full range of scientific views that exist" is suspiciously similar to the 1968 recommendation by the editors of Christianity Today to teach "the full range of views on this topic." The DI language was used in the conference report language of the 2002 No Child Left Behind Act, in a modified version of language authored by Phillip Johnson, and originally introduced into the Senate version of the bill by Senator Rick Santorum. Despite heavy promotion by the DI, the report language has no legal significance (Branch 2002).

What should evolution scientists and educators learn from all this? The lesson is something that we already know: history is important. Specifically, history is crucial for understanding creationist movements and the forms they take. Whenever one is confronted by a proposed policy that attempts to weaken the teaching of evolution, one of the most important things to find out is the policy's history. Who wrote it? Who is promoting it? Why do they think it is important to promote this policy, amongst the thousands of other matters a politician or government actor might be spending time on? Evolution is solid, mainstream science, and until and unless that objectively changes (in reality, and not in the fevered imaginings of a Discovery Institute 
fellow), historical experience shows that there is always going to be (a) a lack of secular justification for the proposed policy and (b) an inevitable finding that "fundamentalist sectarian conviction was and is the law's reason for existence," to quote again the 1968 Epperson court. Such a conclusion, if it can be documented, has obvious relevance for a court's analysis of whether a policy is constitutional. But legal relevance is not the only reason history is important. Often, just asking the questions is enough: deep down, creationists and fundamentalists want to promote their religious views - that's the whole point of all of this effort, in the end-and they do not require much prodding to do so. Once the sectarian goals are out in the open, it often becomes clear to cooler heads that politicians and courts have been in this position many times before, and that the antievolution policy is unwise because the government's job is to teach science in science classes, and let people make up their own minds on religious issues.

Tracing history is obviously not the only thing that is important. There is a place for rebutting creationist objections to evolution (see e.g., Scott and Matzke 2007 and references therein), and explaining evolution to a student or portion of the public, creationist or noncreationist, is no trivial task. These, and many other tasks in evolution education, require more work. But understanding creationist history is not only useful for combating creationist policies. It is perhaps most important because it helps us to understand the creationists as people, rather than viewing them as some kind of mindless horde out to get us. Creationists definitely need to be opposed, and if science education is to remain actual authentic science education, creationist policies need to be excluded from that sphere. Nevertheless, however frustrating the creationists may be at times, we should keep in mind the fact that our dispute with them is a peaceful one taking place in a democracy, and that creationism did not appear ex nihilo, but is the product of Western history and deep-seated, very human fears and desires. Exhibiting some empathy deriving from our shared history might go a long way towards reconciling evangelicals with evolution.

\begin{abstract}
Acknowledgments This article is dedicated to Eugenie Scott, who has been an immense influence in my life. Through her anthropological viewpoint - that is, maintaining her cool and objectivity even under considerable provocation, and where possible maintaining cordial personal relationships with creationists - she helped to teach me and many others that creationists need to be understood as well as opposed. I would also like to give thanks to three anonymous reviewers for detailed and helpful comments.
\end{abstract}

Open Access This article is distributed under the terms of the Creative Commons Attribution Noncommercial License which permits any noncommercial use, distribution, and reproduction in any medium, provided the original author(s) and source are credited.

\section{References}

Alters BJ, Alters S. Defending evolution in the classroom: a guide to the creation/evolution controversy. Sudbury: Jones and Bartlett; 2001.

Anonymous. Hollow victory in Arkansas. Christianity Today. 1968a; 13:27.

Anonymous. The evolutionary bias. Christianity Today. 1968b;12:27.

Anonymous The birth of intelligent design. Telic Thoughts blog. February 1, 2006. Available at: http://telicthoughts.com/the-birthof-intelligent-design/ (retrieved April 10, 2010).

Bennetta WJ. The rise and fall of the Louisiana creationism law, part 1: 'a bold trick'. Terra: the Quarterly Magazine of the Natural History Museum of Los Angeles County. 1988a;26:20-27.

Bennetta WJ. The rise and fall of the Louisiana creationism law, part 2: 'nonsense on stilts'. Terra: the Quarterly Magazine of the Natural History Museum of Los Angeles County. 1988b;27:16-23.

Bird W. Freedom of religion and science instruction in public schools. Yale Law J. 1978;87:515-70.

Bowler PJ. The eclipse of Darwinism: anti-darwinian evolution theories in the decades around 1900. Baltimore: Johns Hopkins University Press; 1983.

Branch G. Farewell to the Santorum amendment? Reports of the National Center for Science Education. 2002;22.

Branch G. The latest polls on creationism and evolution. Reports of the National Center for Science Education. 2004;24.

Bryan WJ. The menace of Darwinism. New York: Revell; 1921.

Darwin C. On the origin of species by means of natural selection. London: Murray; 1859.

Davis PW, Kenyon DH, Thaxton CB. Of pandas and people: the central question of biological origins. Dallas: Haughton; 1993.

Dembski WA and Richards JW. Unapologetic apologetics: meeting the challenges of theological studies. Downers Grove, Ill.: InterVarsity Press; 2001.

Dembski WA, Wells J. The design of life: discovering signs of intelligence in biological systems. Dallas: Foundation for Thought and Ethics; 2008.

Discovery Institute The Wedge. Discovery Institute. 1998. Available at: http://www.antievolution.org/features/wedge.html (retrieved April 10, 2010).

Downey R. Discovery's creation; the wedge: the treatise that launched the discovery institute's campaign for intelligent design. Seattle Weekly. 2006.19. February 1, 2006.

Duncan OD, Geist C. The creationists: how many, who, where? Reports of the National Center for Science Education. 2004;24:26-33.

DYG Inc. Evolution and creationism In public education: an in-depth reading of public opinion. Report of the People for the American Way Foundation, 1-54. March 2000; 2000.

Forrest B, Gross PR. Creationism's Trojan horse: the wedge of intelligent design. Oxford: Oxford University Press; 2007.

Gallup Evolution, Creationism, Intelligent Design. Gallup, Inc. Available at: http://www.gallup.com/poll/21814/evolution-creationismintelligent-design.aspx (retrieved March 23, 2010).

Gould SJ. The structure of evolutionary theory. Cambridge: Belknap Press of Harvard University Press; 2002.

Hodge C. What is Darwinism? New York: Scribner, Armstrong, and company; 1874.

Holmes DL. The faiths of the founding fathers. New York: Oxford University Press; 2006.

International Council on Biblical Inerrancy The Chicago Statement on Biblical Inerrancy. Dallas Theological Seminary. Available at: http://library.dts.edu/Pages/TL/Special/ICBI 1.pdf (retrieved April 10, 2010).

Kitcher P. Living with Darwin: evolution, design, and the future of faith. Oxford: Oxford University Press; 2009. 
Krishtalka L. Don't let creationists corrupt science standards. Pittsburgh: Post-Gazette; 2001.

Larson EJ. Trial and error: the American controversy over creation and evolution. New York: Oxford University Press; 2003.

Majerus MEN. Industrial melanism in the peppered moth, Biston betularia: an excellent teaching example of darwinian evolution in action. Evolution: Education and Outreach. 2008;2:63.

Marsden GM. Understanding fundamentalism and evangelicalism. Grand Rapids: Eerdmans; 1991.

Marsden GM. Fundamentalism and American culture. New York: Oxford University Press; 2006.

Matzke NJ. Design on trial: how NCSE helped win the Kitzmiller case. Reports of the National Center for Science Education. 2006;26:37-44.

Matzke NJ. But isn't it creationism? The beginnings of "intelligent design" in the midst of the Arkansas and Louisiana litigation. In: Ruse M, Pennock RT, editors. But is it science? The philosophical question in the creation/evolution controversy, updated edition. Amherst: Prometheus; 2009. p. 377-413.

Matzke NJ, Gross PR. Analyzing critical analysis: the fallback antievolutionist strategy. In: Scott EC, Branch G, editors. Not in our classrooms: why intelligent design is wrong for our schools. Boston: Beacon; 2006. p. 28-56.

Mawyer M. Arkansas: where creationism lost its shirt. Moody Mon. $1982 ; 82: 10-4$

Mead WR. God's country? Foreign Aff. 2006;85:24-43.

Meyer SC. Signature in the cell: DNA and the evidence for intelligent design. New York: HarperOne; 2009.

Meyer SC, Minnich S, Moneymaker J, Nelson PA, Seelke R. Explore evolution: the arguments for and against neo-Darwinism. Melbourne: Hill House; 2007.

Miller JD, Scott EC, Okamoto S. Public acceptance of evolution. Science. 2006;313:765-6.

Monton BJ. Seeking God in science: an atheist defends intelligent design. Peterborough: Broadview; 2009.

Moore R. Evolution in the courtroom: a reference guide. Santa Barbara, Calif.: ABC-CLIO; 2002.

Moore JN, Slusher HS. Biology: a search for order in complexity. Grand Rapids: Zondervan; 1970.

Morris HM. Scientific creationism. San Diego: Creation-Life; 1974.

Newport F. On Darwin's Birthday, only 4 in 10 believe in evolution. Gallup, Inc. February 12, 2009. Available at: http://www.gallup. com/poll/114544/Darwin-birthday-believe-evolution.aspx (retrieved March 23, 2010).

Noll MA. A history of Christianity in the United States and Canada. Grand Rapids: Eerdmans; 1992.

Noll MA. The scandal of the evangelical mind. Grand Rapids, Mich.: W.B. Eerdmans; 1994.

Noll MA. The bible and slavery. In: Miller RM et al., editors. Religion and the American civil war. New York: Oxford University Press; 1998. p. 43-73.

Noll MA. America's God: from Jonathan Edwards to Abraham Lincoln. Oxford: Oxford University Press; 2002.

Numbers RL. The creationists: from scientific creationism to intelligent design. Cambridge: Harvard University Press; 2006.

OED. "Creationist". In Oxford English dictionary. 2010.

Orr J. Science and christian faith. In: Torrey RA, editor. The Fundamentals; a Testimony to the Truth. Chicago: Testimony; 1910-1915a. p. 334-47.

Orr J. The Early narratives of genesis. In: Torrey RA, editor. The Fundamentals; a Testimony to the Truth. Chicago: Testimony; 1910-1915b. p. 228-40.

Orr J. The holy scriptures and modern negations. In: Torrey RA et al., editors. The Fundamentals; a Testimony to the Truth. Chicago: Testimony; 1910-1915c. p. 94-110.

Padian K. Gross Misrepresentation. Bookwatch Reviews. 1989;2.
Padian K, Matzke NJ. Discovery Institute tries to "swift-boat" Judge Jones. National Center for Science Education. January 4, 2006. Available at: http://www.ncseweb.org/resources/articles/6161 discovery_institute_tries_to_1_4_2006.asp (retrieved March 15).

Padian K, Matzke NJ. Darwin, dover, 'intelligent design' and textbooks. Biochem J. 2009;417:29-42.

Pallen MJ, Matzke NJ. From The Origin of Species to the origin of bacterial flagella. Nature reviews. Immunology. 2006;4:784-90.

Pennock RT. Tower of Babel: the evidence against the new creationism. Cambridge: MIT Press; 1999.

Pennock RT. The postmodern sin of intelligent design creationism. Darwin and Darwinism: Historical, Philosophical and Cultural Studies. 2010;19:4-5

Ratzsch D. There is a place for intelligent design in the philosophy of biology: intelligent design in (philosophy of) biology: some legitimate roles. In: Ayala F, Arp R, editors. Contemporary debates in philosophy of biology. Singapore: Wiley-Blackwell; 2010. p. 343-63.

Ruse M. They're here! Bookwatch Reviews. 1989;2.

Schwabe C. The genomic potential hypothesis: a chemist's view of origins, evolution and unfolding of life. Georgetown, Tex.: Landes Bioscience; 2001.

Scott EC. New creationist book on the way. Reports of the National Center for Science Education 1989;9:21.

Scott EC. Expert witness statement by Eugenie C. Scott. Selman v. Cobb, 1-26. November 17, 2006; 2006.

Scott EC. Evolution vs. Creationism: an Introduction. Berkeley: University of California Press; 2009.

Scott EC, Matzke NJ. Biological design in science classrooms. Proc Natl Acad Sci USA. 2007;104 Suppl 1:8669-76.

Thaxton CB, Bradley WL, Olsen RL. The mystery of life's origin: reassessing current theories. New York: Philosophical Library; 1984.

Torrey RA. Editorial: evolution discredited again. The King's Business. 1918;9:91-100.

Toumey CP. God's own scientists: creationists in a secular world. New Brunswick: Rutgers University Press; 1994.

Warren R. The purpose-driven life: what on earth am I here for? Grand Rapids: Zondervan; 2002.

Wells JC. Charles Hodges' critique of Darwinism: the argument to design. Ph.D., Yale University, 1986.

Wells JC. Charles Hodges' critique of Darwinism: an historical-critical analysis of concepts basic to the 19th century debate. Lewiston: Mellen; 1988.

Wells JC. Icons of evolution: science or myth? Why much of what we teach about evolution is wrong. Washington, DC: Regnery; 2000.

Whitcomb JC, Morris HM. The Genesis Flood; the biblical record and its scientific implications. Philadelphia: Presbyterian and Reformed Publication; 1961.

Wilder-Smith AE. In defense of creationism. Christianity Today. 1968;12:38-9.

\section{Legal Cases Cited}

Epperson v. Arkansas. 1968. 393 U.S. 97. S.Ct., November 12, 1968

Daniel v. Waters. 1975. 515 F.2d. 485. U.S. Court of Appeals, Sixth Circuit, April 10, 1975.

Hendren v. Campbell. 1977. SS Cause No. S577-0139. Marion Superior Court, No. 5, April 14, 1977.

McLean v. Arkansas Board of Education. 1982. 529 F.Supp. 1255. E. D.Ark., January 5, 1982.

Edwards v. Aguillard. 1987. 482 U.S. 578. S.Ct., June 19, 1987.

Kitzmiller v. Dover Area School District. 2005. 400 F.Supp.2d 707. M. D.Pen., December 20, 2005. 